\title{
Implementasi Metode Person In Charge (PIC) dan Monitoring Analisis Kurva-S untuk Percepatan Pengadaan Barang dan Jasa Pembangunan Kabel Laut 150 KV Landing Point Batulicin Kalimantan Selatan
}

\author{
Mikky Noperina Citra ${ }^{1}$; Dhami Johar Dhamiri ${ }^{2}$ \\ ${ }^{1,2}$ Institut Teknologi PLN \\ ${ }^{1}$ mikkynoperinacitra@gmail.com
}

\begin{abstract}
Achievement of the performance of the 2017 contract target of PT PLN (Persero) Central Kalimantan UIP, namely 54 contracted procurement packages and in 2018 there were 57 procurement targets with a temporary budget ceiling of Rp. 1,501,933,269,600.00. So as to achieve the 2018 contracted procurement target it will have an impact on the achievement of the 2019 Commercial Operation Date (COD) efforts needed to accelerate the implementation of goods and services. One of the basic know ledge (common knowledge) for acceleration in a knowledge management construction starts from adding three elements, including: labor, equipment, and overtime / overtime.

After a Root Cause Problem Solver (RCPS) and priority scale selection process are carried out, two priority Problem Solving results have never been implemented as an effort to accelerate implementation, namely Parallel Work with Person In Charge (PIC) Method and Monitoring of Procurement Implementation Schedules with S-Curve Analysis.
\end{abstract}

Keywords: Contracted, Person In Charge (PIC), Package, IDR (Rupiah)

\begin{abstract}
ABSTRAK
Pencapaian kinerja target pengadaan terkontrak 2017 PT PLN (Persero) UIP Kalimantan Bagian Tengah yaitu 54 paket pengadaan terkontrak dan pada tahun 2018 terdapat target pengadaan 57 paket dengan pagu anggaran sementara Rp. 1.501.933.269.600,00. Sehingga untuk mencapai target pengadaan terkontrak 2018 akan berdampak pada pencapaian Commercial Operation Date (COD) tahun 2019 dibutuhkan upaya - upaya percepatan pelaksanaan barang dan jasa. Salah satu pengetahuan mendasar (common knowledge) untuk percepatan dalam sebuah manajemen pengetahuan konstruksi dimulai dari menambah tiga unsur, antara lain: tenaga kerja, peralatan, dan overtime / lembur.

Setelah dilakukan Root Cause Problem Solver (RCPS) dan proses pemilihan skala prioritas, maka dihasilkan dua Problem Solving proritas yang belum pernah dilaksanakan sebagai upaya percepatan pelaksanaan yaitu Kerja Paralel dengan Metode Person InCharge (PIC) dan Monitoring Jadwal Pelaksanaan Pengadaan dengan Analisis Kurva-S.
\end{abstract}

Kata kunci: Terkontrak, Person InCharge (PIC), Paket, IDR (Rupiah) 


\section{Energi dan Kelistrikan: Jurnal Ilmiah}

Vol. 12, No. 1, Januari - Juni 2020, P-ISSN 1979-0783, E-ISSN 2655-5042

https://doi.org/10.33322/energi.v12i1.961

\section{PENDAHULUAN}

Peraturan Menteri Negara BUMN Nomor PER-05/MBU/2008 tentang Pedoman Umum Pelaksanaan Pengadaan Barang dan Jasa BUMN sebagaimana diubah dengan Peraturan Menteri BUMN Nomor PER-15/MBU/2012, memberikan amanat bahwa BUMN sebagai badan usaha perlu melakukan pengadaan barang dan jasa secara cepat, fleksibel, efisien dan efektif agar tidak kehilangan momentum bisnis yang dapat menimbulkan kerugian, sehingga diperlukan pedoman pelaksanaan pengadaan barang dan jasa yang dapat memenuhi kebutuhan bisnis dengan tetap memperhatikan prinsip-prinsip efisien, efektif, kompetitif, transparan, adil dan wajar, serta akuntabel.

Implementasi profesionalisme pengadaan di PT PLN (Persero) sudah dilakukan dengan membuat organisasi pengadaan profesional dan meninggalkan pengadaan sebagai aspek administrasi, pekerjaan sampingan, dan bersifat temporer kepanitiaan, serta tetap menjaga prinsip tata kelola, seperti pembagian tugas dan wewenang.

Pada semester I pencapaian target terkontrak dicapai dengan komposisi tim satu orang pejabat pelaksana barang dan jasa dan dua orang pelaksanaan proyek - proyek pembangkit dan pada semester II terdapat penambahan satu orang pegawai baru. Jumlah sumber daya manusia yang ada untuk mencapai target pengadaan terkontrak 2018 masih terbatas dibandingkan dengan PLN UIP pada umumnya. Sehingga untuk mencapai target pengadaan terkontrak 2018 akan berdampak pada pencapaian Commercial Operation Date (COD) 2019 maka dibutuhkan upaya - upaya percepatan pengadaan barang dan jasa.

PIC singkatan dari Person in Charge. Dapat diartikan, yaitu seseorang yang bertanggung jawab dalam menangani tugas tertentu di dalam kantor. PIC diberikan oleh atasan, seperti manajer atau kepala divisi untuk bawahannya yang dianggap berkompeten dalam menangani tugas tersebut. Tugas yang dimaksud sifatnya bisa jangka panjang atau jangka pendek. Dalam waktu tertentu, orang yang diberikan tanggung jawab di PIC harus melaporkan kepada atasannya terkait perkembangan tugas yang diembannya.

Dari pemasalahantentang pengadaan barang di PT.PLN maka penulis bermaksud mengadakan penilitian tentang penerapan metode Person In Charge (PIC) dan kurva S dengan judul penelitian Implementasi metode Person In Charge (PIC) dan monitoring analisis kurva - s untuk percepatan pengadaan barang dan jasa pembangunan kabel laut $150 \mathrm{KV}$ landing point batulicin, kalimantan selatan.

\section{METODE PENELITIAN}

Dalam penelitian ini menggunakan metode kuantitatif dimana data yang didapatkan dilapangan akan diolah dan digunakan untuk dianalisa sehingga mendapatkan kesimpulan akhir bagaimana metode person in charge (PIC) Dan monitoring kurva -s dapat mempercepat pengadaan barang dan jasa pembangunan kabel laut $150 \mathrm{KV}$ landing point batu licin, Kalimantan selatan.

Pekerjaan pembangunan kabel laut $150 \mathrm{kV}$ landing point Batu licin - landing point Pulau Laut merupakan pekerjaan penyaluran daya listrik melalui 2 (dua) jalur kabel bawah laut $150 \mathrm{kV}$ sepanjang kurang lebih $4 \mathrm{~km}$ dari Batu licin ke Pulau Laut. Lokasi pekerjaan ini terletak di Provinsi Kalimantan Selatan seperti tampak pada gambar 2.1. List posisi jalur kabel laut $150 \mathrm{kV}$ yang direncanakan seperti tampak pada tabel 1 dengan mengacu pada Peraturan Menteri Perhubungan No. 129 tahun 2016. Kedalaman seabed (dasar laut) jalur kabel laut rata-rata kurang dari 15 m, maka seluruh kabel laut ditanam dikedalaman parit 1-2 meter. Ruang lingkup pekerjaan meliputi pengadaan material utama, pekerjaan persiapan, pekerjaan instalasi, as built drawing, pemasukan jalur kabel pada peta international, garansi dan pemeliharaan. 


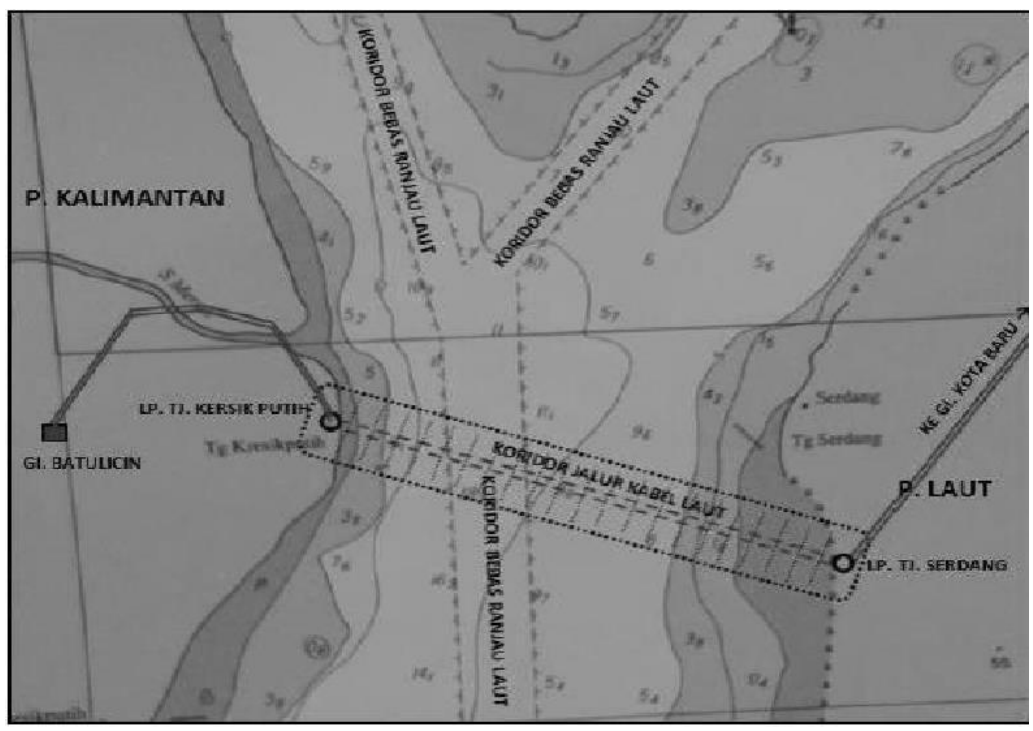

Gambar 1. Lokasi Pekerjaan.

Tabel 1. List Posisi Jalur Kabel Laut $150 \mathrm{kv}$

\begin{tabular}{|c|c|c|c|c|c|}
\hline \multicolumn{6}{|l|}{ Sirkuit 1} \\
\hline Nama & $\begin{array}{l}\text { Koordin } \\
\text { at } \\
\text { Lintang }\end{array}$ & $\begin{array}{l}\text { Koordin } \\
\text { at Bujur }\end{array}$ & $\begin{array}{l}\text { Kedalama } \\
\mathrm{n}(\mathrm{m})\end{array}$ & $\begin{array}{l}\text { Seabed } \\
\text { (kondi } \\
\text { si dasar laut) }\end{array}$ & Proteksi \\
\hline $\begin{array}{l}\text { LP } \\
\text { Batulicin }\end{array}$ & $3^{\circ}{ }^{\circ} 28^{\prime} 53.52 " \mathrm{~S}$ & $\begin{array}{l}116^{\mathrm{O}} 0^{\prime} 48.50^{\prime \prime} \\
\mathrm{E}\end{array}$ & 0 & Pantai & $\begin{array}{l}\text { Concret } \\
\text { e shell }\end{array}$ \\
\hline TP11 & $3^{\circ} 2^{\prime} 9^{\prime} .23 " \mathrm{~S}$ & $116^{\circ} 1^{\prime} 0.87^{\prime \prime} \mathrm{E}$ & 6 & Lumpur & Parit $2 \mathrm{~m}$ \\
\hline TP12 & 3029'21.49"S & 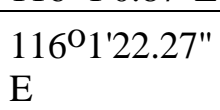 & 17 & Pasir & Parit $1 \mathrm{~m}$ \\
\hline TP13 & $3^{\circ} 30^{\prime} 1.02 " \mathrm{~S}$ & $\begin{array}{l}116^{\circ} 2^{\prime} 19.07^{\prime \prime} \\
\mathrm{E}\end{array}$ & 2 & Lumpur & Parit $2 \mathrm{~m}$ \\
\hline $\begin{array}{l}\text { LP } \\
\text { Kotabaru }\end{array}$ & $3^{0} 30^{\prime} 6.93 " \mathrm{~S}$ & $\begin{array}{l}116^{0} 2^{\prime} 30.31^{\prime \prime} \\
\mathrm{E}\end{array}$ & 0 & Pantai & $\begin{array}{l}\text { Concret } \\
\text { e shell }\end{array}$ \\
\hline \multicolumn{6}{|l|}{ Sirkuit 2} \\
\hline Nama & $\begin{array}{l}\text { Koordin } \\
\text { at } \\
\text { Lintang }\end{array}$ & $\begin{array}{l}\text { Koordin } \\
\text { at Bujur }\end{array}$ & $\begin{array}{l}\text { Kedalama } \\
\mathrm{n}(\mathrm{m})\end{array}$ & $\begin{array}{l}\text { Seabed } \\
\text { (kondi } \\
\text { si dasar laut) }\end{array}$ & Proteksi \\
\hline $\begin{array}{l}\mathrm{LP} \\
\text { Batulicin }\end{array}$ & $3^{0} 28^{\prime} 53.52^{\prime \prime} \mathrm{S}$ & $\begin{array}{l}116^{\circ} 0^{\prime} 48.50^{\prime \prime} \\
\mathrm{E}\end{array}$ & 0 & Pantai & $\begin{array}{l}\text { Concret } \\
\text { e shell }\end{array}$ \\
\hline TP11 & $3^{30} 28^{\prime} 29.85^{\prime \prime} \mathrm{S}$ & $116^{\circ} 1^{\prime} 3.66^{\prime \prime E}$ & 6 & Lumpur & Parit $2 \mathrm{~m}$ \\
\hline TP12 & 3029'26.78"S & $\begin{array}{l}116^{\circ} 1^{\prime} 37.82^{\prime \prime} \\
\mathrm{E}\end{array}$ & 17 & Pasir & Parit $1 \mathrm{~m}$ \\
\hline TP13 & $3^{\circ 0} 29^{\prime} 58.32 " \mathrm{~S}$ & $\begin{array}{l}116^{\circ} 2^{\prime 2} 20.21 " \\
\mathrm{E}\end{array}$ & 2 & Lumpur & Parit $2 \mathrm{~m}$ \\
\hline $\begin{array}{l}\text { LP } \\
\text { Kotabaru }\end{array}$ & $3^{\circ 0} 30^{\prime} 6.93 " \mathrm{~S}$ & $\begin{array}{l}116^{0} 2^{\prime} 30.31^{\prime \prime} \\
\mathrm{E}\end{array}$ & 0 & Pantai & $\begin{array}{l}\text { Concret } \\
\text { e shell }\end{array}$ \\
\hline
\end{tabular}




\section{Energi dan Kelistrikan: Jurnal Ilmiah}

Vol. 12, No. 1, Januari - Juni 2020, P-ISSN 1979-0783, E-ISSN 2655-5042

https://doi.org/10.33322/energi.v12i1.961

\section{PEMBAHASAN DAN HASIL}

\subsection{Pemilihan Metode Pemecahan Masalah}

Analisis kebutuhan dalam pendekatan masalah "Target Pengadaan Terkontrak 2017 PLN UIP Kalbagteng (Kalimantan Bagian Tengah) yang tidak tercapai" dapat dicari penyebab dan akar permasalahan dengan metode Root Cause Problem Solving (RCPS), yaitu dengan menggunakan pertanyaan Why beberapa tingkat sehingga dapat dilakukan identifikasi alternatif - alternatif solusi perbaikan maupun memilih solusi terbaik untuk mengatasi permasalahan tersebut. Metode ini digunakan untuk mengenali masalah atau ketidak sesuaian sehingga diperoleh akar penyebab dari suatu masalah. Metode ini digunakan untuk memperbaiki atau menghilangkan masalah, dan mencegah agar tidak terjadi lagi.sebagai berikut:

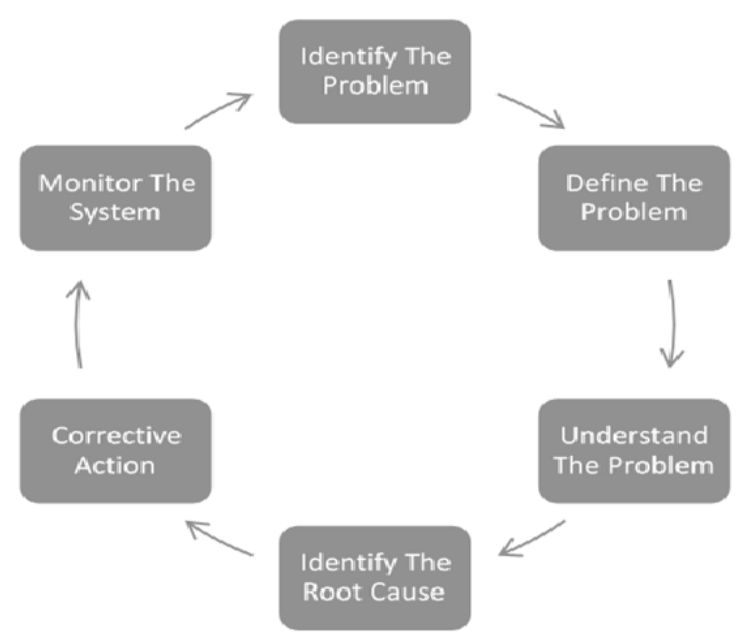

Gambar 2. Flowchart Analisis RCPS

\subsection{Perancangan Penelitian}

Perancangan penelitian dimulai dari Implementasi Analisis permasalahan dengan mencari akar-akar dari permasalahan beberapa tahap dan dilanjut dengan mencari problem solving sesuai Analisis RCPS pada gambar dibawah ini yaitu: 


\section{Energi dan Kelistrikan: Jurnal Ilmiah}

Vol. 12, No. 1, Januari - Juni 2020, P-ISSN 1979-0783, E-ISSN 2655-5042 https://doi.org/10.33322/energi.v12i1.961

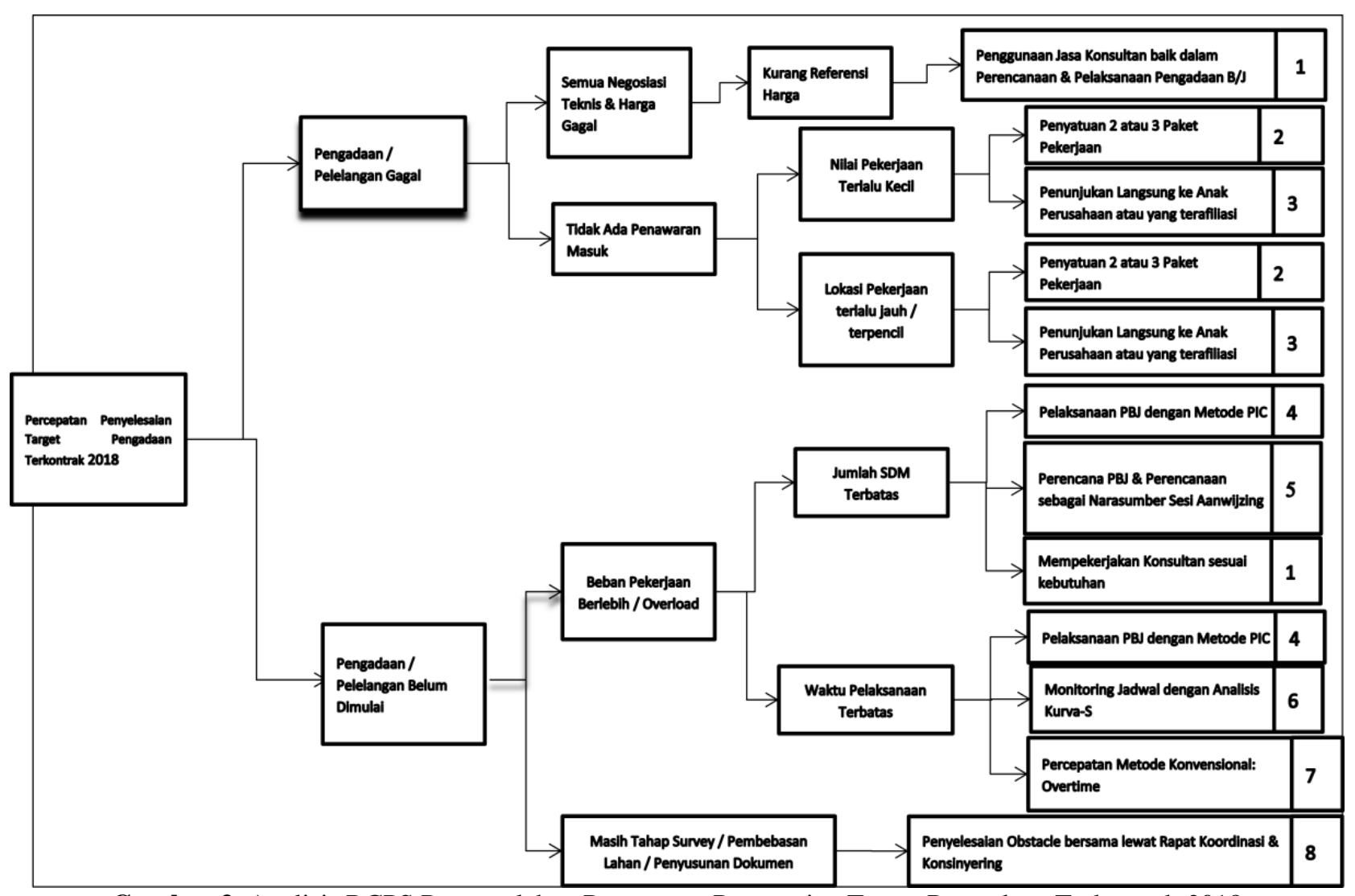

Gambar 3. Analisis RCPS Permasalahan Percepatan Pencapaian Target Pengadaan Terkontrak 2018

\subsection{Person In Charge (PIC)}

Pendekatan penyelesaian masalah adalah melalui langkah-langkah analitis. Metode PIC (Person In Charge) atau Penanggung Jawab artinya menyerahkan seluruh proses pelaksanaan pengadaan barang \& jasa secara penuh kepada PIC terpilih tersebut. Hal ini berbeda sekali dari proses pelaksanaan pengadaan barang \& jasa konvensional yang mana setiap tahap dikerjakan seluruh anggota tim dengan menugaskan satu orang melaksanakan administrasi. Berikut ini gambar dibawah ini merupakan Deskripsi Tugas PIC dalam setiap menangani proses pelaksanaan Pengadaan Barang \& Jasa. 


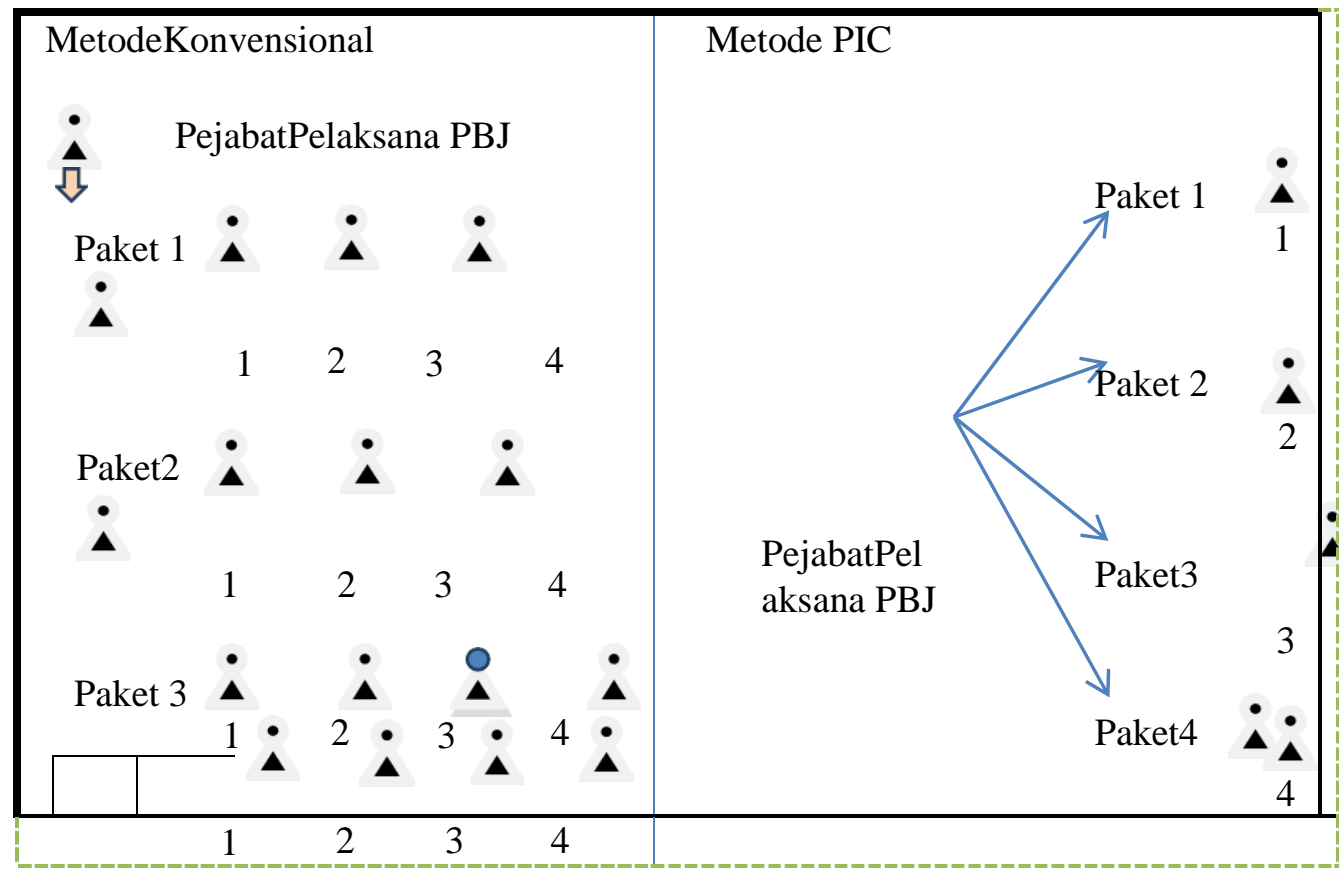

Gambar 4. DeskripsiTugas PIC Pelaksana Pengadaan Barang dan Jasa

\subsection{Analisis Manajemen Resiko}

Tabel 2. Perbandingan dengan Percepatan Metode PIC terhadap Percepatan Metode Konvensional

\begin{tabular}{|c|l|c|c|}
\hline No & TahapPelaksanaanPengadaan B/J & Metodekonvensional & Metode PIC \\
\hline 1. & Undangan\&Pengambilan RKS & $\mathbf{7}$ & $\mathbf{7}$ \\
\hline 2. & Aanwijzing \& Site Visit & $\mathbf{5}$ & $\mathbf{3}$ \\
\hline 3. & $\begin{array}{l}\text { Pemasukan \& Pembukaan Penawaran } \\
\text { Sampul 1 }\end{array}$ & $\mathbf{1 8}$ & $\mathbf{1 8}$ \\
\hline 4. & EvaluasiPenawaranSampul 1 & $\mathbf{4}$ & $\mathbf{5}$ \\
\hline 5. & PembukaanPenawaranSampul 2 & $\mathbf{1}$ & $\mathbf{1}$ \\
\hline 6. & PembukaanPenawaranSampul 2 & $\mathbf{4}$ & $\mathbf{4}$ \\
\hline 7. & Klarifikasi\&Negosiasi & $\mathbf{4}$ & $\mathbf{1}$ \\
\hline 8. & PenetapanPemenang & $\mathbf{1}$ & $\mathbf{1}$ \\
\hline 9. & Masasanggah & $\mathbf{3}$ & $\mathbf{3}$ \\
\hline 10. & Jawabansanggah & $\mathbf{2}$ & $\mathbf{2}$ \\
\hline 11. & MasaSanggah Banding (Bilaada) & $\mathbf{0}$ & $\mathbf{0}$ \\
\hline 12. & JawabanSanggah (Bila Ada) & $\mathbf{0}$ & $\mathbf{1}$ \\
\hline 13. & PenunjukanPemenang & $\mathbf{1}$ & $\mathbf{1}$ \\
\hline 14. & CDA & $\mathbf{4}$ & $\mathbf{1}$ \\
\hline 15. & PenandatangananPerjanjian & $\mathbf{1}$ & $\mathbf{4 8}$ \\
\hline & Total & $\mathbf{5 5}$ & \\
\hline
\end{tabular}




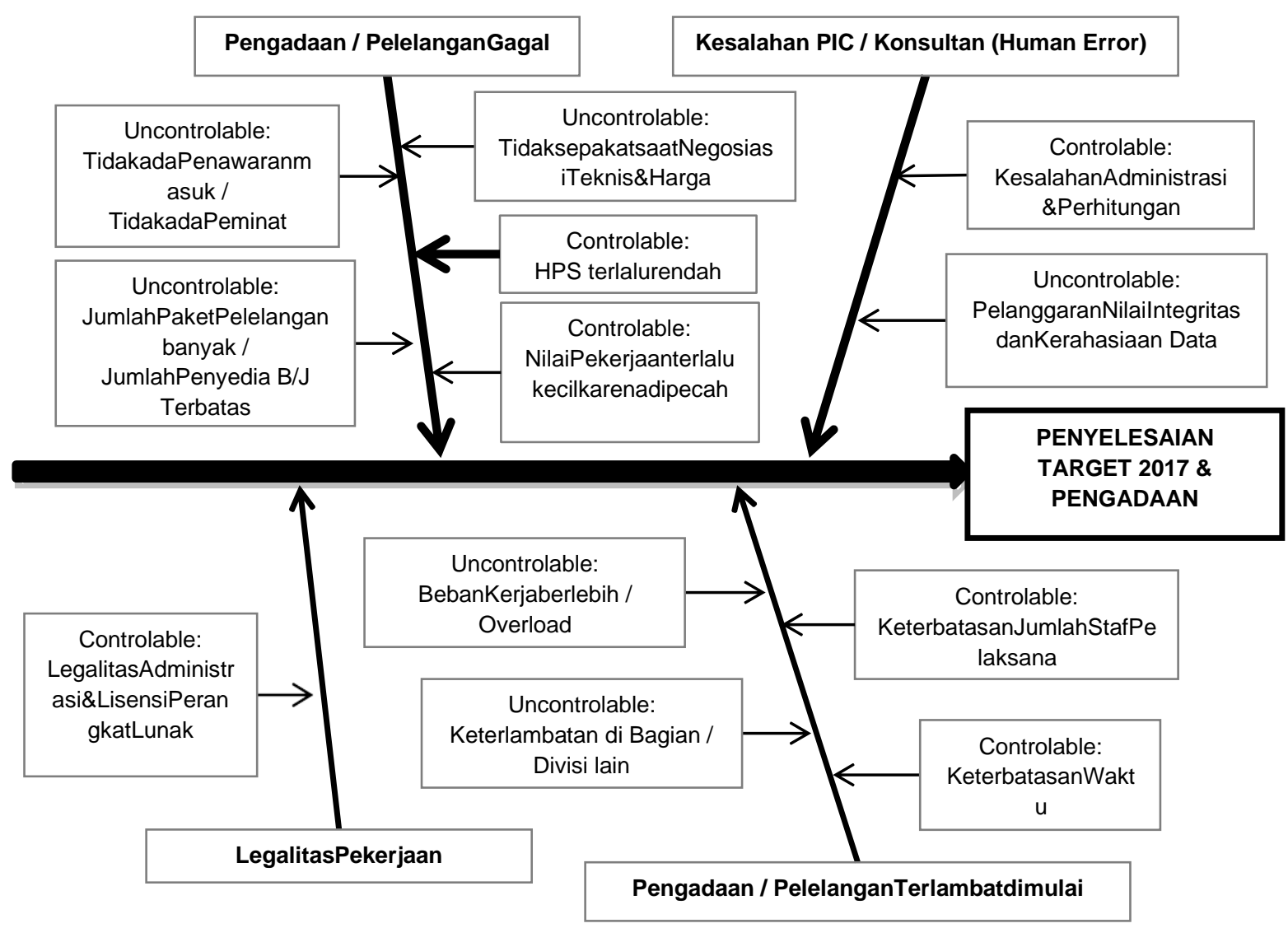

Gambar 5. Root Cause Analysis denganmetode Fishbone untuk Assessment Management Risiko

Hasil Pelaksanaan Program Terbaru Percepatan Proses Pengadaan Barang dan jasa dengan metode PIC dibandingkan dengan percepatan dengan metode konvensional dapat langsung dirasakan perubahannya. Berikut tabel dibawah ini durasi waktu (dalam hari) yang dibutuhkan pelaksanaan pengadaan dengan percepatan metode konvensional dan percepatan dengan metode PIC (asumsi: 4 paket pelelangan terbatas, dari jenis pekerjaan dan DPT yang berbeda, setiap paket ada 4 calon penyedia barang dan jasa yang mendaftar).

Dari seluruh target penyelesaian sisa target pengadaan konstruksi terkontrak 2017 sudah ada pencapaian parsial di Maret 2018 terhadap Desember 2017, sebagai berikut: 


\section{Energi dan Kelistrikan: Jurnal Ilmiah}

Vol. 12, No. 1, Januari - Juni 2020, P-ISSN 1979-0783, E-ISSN 2655-5042

https://doi.org/10.33322/energi.v12i1.961

Tabel 3. Pencapaian Parsial Pengadaan Terkontrak 1 April 2018 terhadap 2017

\begin{tabular}{|c|c|c|c|}
\hline No & Nama Pengadaan 2017 & $\begin{array}{l}\text { Tanggal } \\
\text { Kontrak }\end{array}$ & $\begin{array}{c}\text { Nilai } \\
\text { Kontrak (Rp) }\end{array}$ \\
\hline \multicolumn{4}{|c|}{ Semester $1-2017$} \\
\hline 1 & $\begin{array}{l}\text { PekerjaanjasaiventarisasidandentifikasikepemilikandanPenyu } \\
\text { sunanpetaobjektanahdibawahruangbebas / right of } \\
\text { way (ROW) SUTT } 150 \mathrm{KV} \text { Buntok- Muarateweh }\end{array}$ & $\begin{array}{l}20 \text { Januari } \\
2017\end{array}$ & $473,990,000$ \\
\hline 2 & $\begin{array}{l}\text { Pekerjaan Jasa Konsultasi Penilaian Ganti Rugi Tanah untuk } \\
\text { Tapak Tower SUTT } 150 \text { kV Kasongan - Kuala Kurun T.01- } \\
\text { T.150) }\end{array}$ & $\begin{array}{l}17 \text { Februari } \\
2017\end{array}$ & $311,685,000$ \\
\hline 3 & $\begin{array}{l}\text { Pekerjaan Pembangunan } 4 \text { LINE BAY, } 2 \text { TRAFO BAY DAN } \\
\text { 1 BUS COUPLER } \\
\text { GARDU INDUK } 150 \text { KV PANGKALAN BUN }\end{array}$ & $\begin{array}{l}8 \text { Maret } \\
2017\end{array}$ & $80,700,884,000$ \\
\hline 4 & $\begin{array}{l}\text { Pekerjaan Jasa Konstruksi Renovasi Gedung Kantor dan } \\
\text { Musholla }\end{array}$ & $\begin{array}{l}24 \text { Maret } \\
2017\end{array}$ & $2,350,000,000$ \\
\hline & Total Pengadaan Terkontrak 1 Januari - 1 April 2017 & & $83,836,559,000$ \\
\hline No & Nama Pengadaan 2018 & $\begin{array}{l}\text { Tanggal } \\
\text { Kontrak }\end{array}$ & $\begin{array}{l}\text { Nilai Kontrak } \\
\quad(\text { Rp) }\end{array}$ \\
\hline \multicolumn{4}{|c|}{ SUTT Kalimantan Selatan } \\
\hline 1 & $\begin{array}{l}\text { Inventarisasi dan Identifikasi Kepemilikan, Penyusunan Peta } \\
\text { Objek Tanah, Bangunan dan Tanaman di bawah ROW di } \\
\text { Kalsel Tahun 2018-2019 }\end{array}$ & $\begin{array}{l}27 \text { Maret } \\
2018\end{array}$ & KHS \\
\hline 2 & $\begin{array}{l}\text { Kabel Laut } 150 \text { kV Landing Point Batulicin - Landing } \\
\text { Point P.Laut }\end{array}$ & $\begin{array}{l}\text { 6 Maret } \\
2018\end{array}$ & $123,523,602,000$ \\
\hline \multicolumn{4}{|c|}{ Gardu Induk Kalimantan Selatan } \\
\hline \multicolumn{4}{|c|}{ SUTT Kalimantan Tengah } \\
\hline 3 & $\begin{array}{l}\text { Inventarisasi dan Identifikasi Kepemilikan, Penyusunan Peta } \\
\text { Objek Tanah, Bangunan dan Tanaman di bawah ROW di } \\
\text { Kalteng Tahun 2018-2019 }\end{array}$ & $\begin{array}{l}28 \text { Maret } \\
2018\end{array}$ & KHS \\
\hline \multicolumn{4}{|c|}{ Gardu Induk Kalimantan Tengah } \\
\hline \multicolumn{4}{|c|}{ Pembangkit } \\
\hline \multicolumn{4}{|c|}{ Rutin \& Umum \& Tambahan } \\
\hline 4 & pemboronganjasapenyediaantransportasi di lingkungan UPP 2 & $\begin{array}{l}20 \text { Maret } \\
2018\end{array}$ & $6,795,724,100$ \\
\hline 5 & pemboronganjasapenyediaantransportasi di lingkunganUPP 3 & $\begin{array}{l}20 \text { Maret } \\
2018 \\
\end{array}$ & $4,985,007,500$ \\
\hline & TOTAL PENGADAAN 2018 & & $135,304,333,600$ \\
\hline
\end{tabular}


Pada gambar dibawah ini merupakan contoh monitoring terhadap Analisis Kurva-S Pengadaan Kabel Laut, terlihat adanya deviasi antara rencana (plan) dengan actual yang menggambarkan adanya potensi keterlambatan, sehingga bisa dilakukan tindak lanjut untuk mencegah keterlambatan pengadaan terkontrak.

Tabel 4. Contoh Monitoring AnalisisKurva-S Plan v Aktual

\begin{tabular}{|c|c|c|c|c|c|c|c|c|c|c|c|c|c|c|c|c|c|c|c|c|c|c|c|c|c|}
\hline \multicolumn{25}{|c|}{ KURVAS S SCHEDULE PENGADAAN PEKERJAAN SUTT 150 KV KABEL LAUT LANDING POINT BATU LICIN - LANDING POINT PULAU LAUT } & \\
\hline \multirow{2}{*}{ № } & \multirow{2}{*}{ Kegiattan } & \multirow{2}{*}{ BOBOT } & \multirow{2}{*}{ Durasi } & \multirow{2}{*}{$\begin{array}{c}\text { Tanggal } \\
\text { Mulai }\end{array}$} & \multirow{2}{*}{$\begin{array}{l}\text { Tanggal } \\
\text { Selesai }\end{array}$} & \multicolumn{4}{|c|}{ NOVEMBER } & \multicolumn{4}{|c|}{ DECEMBER } & \multicolumn{4}{|c|}{ JANUARY } & \multicolumn{4}{|c|}{ FEBRUARY } & \multicolumn{4}{|c|}{ MARCH } \\
\hline & & & & & & 1 & 2 & 3 & 4 & 1 & 2 & 3 & 4 & & 2 & 3 & 4 & 1 & 2 & 3 & 4 & & 2 & & \\
\hline 1 & Pengumuman prakualfikasi & 4.76 & 1 & 6-Nov-17 & 6-Nov-17 & 4.76 & & & & & & & & & & & & & & & & & & & \\
\hline 2 & Pengambilan dokumen prakualifikasi & 4.76 & 12 & 6-Nov-17 & 21-Nov-17 & 1.59 & 1.59 & 1.59 & & & & & & & & & & & & & & & & & \\
\hline 3 & Pemasukan dokumen prakualfikasi & 4.76 & 12 & 13-Nov-17 & 28-Nov-17 & 1.19 & 1.19 & 1.19 & 1.19 & & & & & & & & & & & & & & & & \\
\hline 4 & Evaluasi dokumen prakualfikasi & 4.76 & 5 & 29-Nov-17 & 5-Dec-17 & & & & 2.38 & 2.38 & & & & & & & & & & & & & & & \\
\hline 5 & Pengumuman hasil prakualfikikasi & 4.76 & 1 & 5-Feb-18 & 5-Feb-18 & & & & & & & & & & & & & 4.76 & & & & & & & \\
\hline 6 & Masa sanggah & 4.76 & 3 & 5-Feb-18 & 7-Feb-18 & & & & & & & & & & & & & 4.76 & & & & & & & \\
\hline 7 & Undangan kepada penyedia barang/jasa & 4.76 & 1 & 5-Feb-18 & 5-Feb-18 & & 5 & & 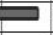 & Plan & & & & & & & & 4.76 & & & & & & & \\
\hline 8 & Pengambilian dokumen pelelangan/ RKS & 4.76 & 2 & 6-Feb-18 & 7-Feb-18 & & 5 & & 0 & Aktual & & & & & & & & 4.76 & & & & & & & \\
\hline 9 & Penjelasan dokumen pelelangan/RKS & 4.76 & 1 & 7-Feb-18 & 7-Feb-18 & & & & & & & & & & & & & 4.76 & & & & & - & & \\
\hline 10 & Pemasukan dokumen penawaran & 4.76 & 19 & 8-Feb-18 & 7-Mar-18 & & & & & & & & & & & & & & 1.19 & 1.19 & 1.19 & 1.19 & 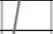 & & \\
\hline 11 & Pembukaan dokumen penawaran sampul satu & 4.76 & 1 & 8-Mar-18 & 8-Mar-18 & & & & & & & & & & & & & & & & & & 4.76 & & \\
\hline 12 & Evaluasi dokumen sampul satu & 4.76 & 2 & 8-Mar-18 & 9-Mar-18 & & & & & & & & & & & & & & & & & & $4 / 6$ & & \\
\hline 13 & Pembukaan dokumen penawaran sampul dua & 4.76 & 1 & 12-Mar-18 & 12-Mar-18 & & & & & & & & & & & & & & & & & & 4.76 & & \\
\hline 14 & Evaluasi dokumen sampul dua & 4.76 & 1 & 12-Mar-18 & 12-Mar-18 & & & & & & & & & & & & & & & & & - & 4.76 & & \\
\hline 15 & Klarifikasi \& negosiasi & 4.76 & 1 & 13-Mar-18 & 13-Mar-18 & & & & & & & & & & & & & & $\approx$ & 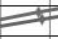 & & & 4.76 & & \\
\hline 16 & Usulan penetapan pemenang & 4.76 & 1 & 14-Mar-18 & 14-Mar-18 & & & & & & & & & & & & & 7 & & & & & 4.76 & & \\
\hline 17 & Penetapan pemenang & 4.76 & 1 & 14-Mar-18 & 14-Mar-18 & & & & & & & & & & & & & T & & & & & 4.76 & & \\
\hline 18 & Pengumuman pemenang & 4.76 & 1 & 14-Mar-18 & 14-Mar-18 & & & & & & & & & & & & & $T$ & & & & & 4.76 & & \\
\hline 19 & Sanggahan & 4.76 & 3 & 14-Mar-18 & 16-Mar-18 & & & & & & & & & & & & & & & & & & 2.38 & 2.38 & \\
\hline 20 & Jawaban sanggahan & - & 0 & & & & & & & & & & & & & & & & & & & & & & \\
\hline 21 & Sanggah banding & - & 0 & & & & & & & & & & & & & & & & & & & & & & \\
\hline 22 & Jawaban sanggah banding & - & 0 & & & & & & & & & & & & & & & & & & & & & & \\
\hline 23 & Penunjukan pemenang & 4.76 & 1 & 19-Mar-18 & 19-Mar-18 & & & & & & & & & & & & & & & & & & & 4.76 & \\
\hline 24 & Tandatangan kontrak & 4.76 & 1 & 20-Mar-18 & 20-Mar-18 & H & & & & & & & & & & & & & & & & & & 4.76 & \\
\hline & & 100.00 & & & & & & & & & & & & & & & & & & & & & & & \\
\hline & & & & & MINGGUAN & 7.54 & 2.78 & 2.78 & 3.57 & 2.38 & . & . & . & . & - & . & - & 23.81 & 1.19 & 1.19 & 1.19 & 1.19 & 40.48 & 11.90 & \\
\hline & & & & & KUMULATIF & 7.54 & 10.32 & 13.10 & 16.67 & 19.05 & 19.05 & 19.05 & 19.05 & 19.05 & 19.05 & 19.05 & 19.05 & 42.86 & 44.05 & 45.24 & 46.43 & 47.62 & 88.10 & 100.00 & \\
\hline
\end{tabular}

\section{KESIMPULAN DAN SARAN}

\subsection{KESIMPULAN}

Hasil Program Terobosan berupa Percepatan Pengadaan dengan metode PIC dan monitoring analisis kurva $-\mathrm{S}$ memberikan hasil dan dampak parsial (periode 1 januari - 1 april 2018 terhadap 1 januari -1 april 2017), sebagai berikut:

Tabel 5. Perbandingan percepatan pegadaan mengunakan metode PIC terhadap metode Konvensional

\begin{tabular}{|l|l|l|}
\hline \multicolumn{1}{|c|}{$\begin{array}{c}\text { Kriteria perbandingan } \\
\text { Percepatan }\end{array}$} & \multicolumn{1}{|c|}{$\begin{array}{c}\text { Metode Konvensional } \\
\mathbf{( 2 0 1 7 )}\end{array}$} & \multicolumn{1}{|c|}{ Metode PIC (2018) } \\
\hline Jumlah hari & 55 hari & 48 hari \\
\hline $\begin{array}{l}\text { Paket terkontrak } \\
(1 \text { januari }-1 \text { april })\end{array}$ & 4 paket & 5 paket \\
\hline $\begin{array}{l}\text { Nilai Terkontrak } \\
(1 \text { januari }-1 \text { april })\end{array}$ & IDR 83.836 .559 .000 .00 & IDR 21.446 .497 .765 .00 \\
\hline Saving dan gain & IDR 0,00 & IDR 21.446 .497 .765 .00 \\
\hline
\end{tabular}




\section{Energi dan Kelistrikan: Jurnal Ilmiah}

Vol. 12, No. 1, Januari - Juni 2020, P-ISSN 1979-0783, E-ISSN 2655-5042

https://doi.org/10.33322/energi.v12i1.961

\subsection{SARAN}

Rekomendasi untuk Penerapan Program Terobosan berupa Percepatan Pelaksanaan Pengadaan dengan Metode PIC dan Monitoring Analisis Kurva-S , perlu memperhatikan hal- hal sebagai berikut:

1. Diusulkan dibuat Keputusan General Manager untuk Percepatan Pelaksanaan Pengadaan dengan Metode PIC dan Pedoman Tata Cara Pemilihan PIC Pelaksanaan Pengadaan B/J.

2. Mengadakan COC rutin mengenai PLN Berintegritas, pentingnya menjaga integritas, dan risiko bahaya suap \&gratifikasi; mengingat risiko tinggi pekerjaan pelaksanaan pengadaan $\mathrm{b} / \mathrm{j}$.

\section{UCAPAN TERIMAKASIH}

Penulis mengucapkan terima kasih kepada PT. PLN (persero) UIP KALBAGTENG yang telah memberi dukungan yang membantu pelaksanaan penelitian dan atau penulisan artikel.

\section{DAFTAR PUSTAKA}

[1] Datasheet Kabel Listrik. (2013). Laporan Produksi Kabel Listrik. Jakarta: PT Voksel Electrik Tbk, PT Sucaco Tbk.

[2] Keputusan Direksi PT. PLN (Persero) Nomor: 620.K/DIR/2012 dan nomor: 527.K/DIR/2014 TENTANG Pedoman Pengadaan Barang/jasa PT.PLN(Persero), Jakarta.

[3] Rencana Usaha Penyediaan Tenaga Listrik (RUPTL) PT. PLN (Persero) 2017-2026.

[4] Fayol, Henri (1917), Administration industrielle et generale; prevoyance, organisation, commandement, coordination, controle (in French), Paris, H. Dunod et E. Pinat.

[5] Flowchart Analisis RCPS, Vorley, 2008.

[6] Unas, Saifoe El. Manajemen Proyek /2012/01/Controlling-Kurva-S-Tracking.pdf

[7] Abrar, Husein. 2008. Manajemen Proyek, perencanaan, penjadwalan \& pengendalian proyek. Yogyakarta: Andi.

[8 https://www.academia.edu/23115490/PETUNJUK_TEKNIS_PENGADAAN_BARANG_ DAN_JA SA_PT_PLN_PERSERO_

[9] Dreger, J. Brian. New York 1992 Proyek Manajemen

[10] UNS-Fak. ISIP Prog. D III Manajemen Administrasi-D1510071-2013

[11] Ryan, Albert. 2011. Buku Pengangan Pengadaan Barang dan Jasa. Gradien Mediatama, Yogjakarta

[12] White, D. 1996. Application of Systems Thinking to Risk Management: A Rivew of The Literature. Management Decision 33(10): 34-35. Williams, S., M. Zainuba, dan

[13] Rencana Usaha Penyediaan Tenaga Listrik (RUPTL) PT PLN (Persero) 2017-2026 